matter still much in mind, along with the allied question of statutory levies to finance other desirable co-operative activities. The Government does not wish to discourage industries which have plans under consideration from proceeding to work them out in detail, even if those plans will ultimately need statutory power to give effect to them. Emphasizing the importance which the Government attaches to a rapid improvement in the scientific basis of our industrial production, Lord Pakenham said that the Government could do a little to help in that matter; but primarily such improvement must depend on the willingness of industrialists themselves to devote resources to research, and it must depend still more on their willingness to exploit the results of scientific research.

\section{Dr. A. D. Imms, F.R.S.}

DR. A. D. Imms has retired from the readership in entomology at Cambridge, which he had held with distinction since 1931. Dr. Imms was the first holder of this readership, the establishment of which resulted from an endowment by the Rockefeller Foundation, made with the avowed intent of strengthening in Great Britain those sciences which are fundamental for agriculture. The appointment of Dr. Imms seemed almost inevitable. After taking his degree in London, Dr. Imms held an 1851 Research Scholarship at Corpus Christi College, Cambridge, during 1905-7, and then took up the appointment of professor of biology in the University of Allahabad; for two years, during 1911-13, he was forest zoologist to the Government of India, after which he became reader in agrieultural entomology at Manchester, establishing there a tradition for entomological research which has lived on. But it was not until his transfer to Rothamsted in 1918 as chief entomologist that his full stature came to be appreciated. In 1924 Dr. Imms published his "Text-book of Entomology", and at once he became recognized as the leader of entomology in Grest Britain. This excellent book has gone through three editions, and is almost as widely used in the United States as it is in Britain. "Recent Advances in Entomology" followed in 1931, and during the War Dr. Imms produced an admirable "Introduction to Entomology". The influence of these books has been immense, and will long continue. It is good to know that Dr. Imms intends to pursue his literary work in the milder climate of Devon, and we may hope that the entomological world at large may long enjoy what Cambridge has regretfully lost.

\section{Dr. V. B. Wigglesworth, F.R.S.}

DR. V. B. WIGglesworth has been appointed to the readership in entomology in the Department of Zoology, Cambridge, vacated by Dr. A. D. Imms. In addition, he is in charge of a Unit of Insect Physiology of the Agricultural Research Council. After some postgraduate work in biochemistry at Cambridge, Wigglesworth held posts in the Department of Entomology at the London School of Hygiene and Tropical Medicine, during 1921-43. The Department was under P. A. Buxton, who was interested in precise field-work on the ecology of insects, and Wigglesworth made complementary studies on physiology, exploring many sides of the subject, including the behaviour of insects. His work went deeply into the pure science, the view being taken that a proper understanding of physiology is one of the foundations of applied entomology. He showed himself a master of the carefully planned experiment and of the simple technique. Not infrequently his experiments with insects have proved to be important contributions to general physiology. His book, "The Principles of Insect Physiology", first published in 1939 , is an important contribution to biological science.

\section{Dr. Kenneth Mellanby}

Dr. Kenneth Merlanby has been appointed to the University readership in entomology tenable at the London School of Hygiene and Tropical Medicine in succession to Dr. Wigglesworth as from October 1. During 1930-36 Dr. Mellanby was engaged in research work at the London School of Hygiene and Tropical Medicine, and in 1936 he was elected Sorby research fellow of the Royal Society. He joined the R.A.M.C. in 1943, but was released in 1944 in order to proceed to South-East Asia for research on behalf of the Medical Research Council.

\section{Earthquake in the Arabian Sea}

The greatest shock ever recorded by the Riverview Observatory, Australia, was registered by seismographs throughout the world about 10.6 p.m. G.M.T. on November 27. The epicentre may have been near lat. $24^{\circ} \mathrm{N}$., long. $64 \cdot 5^{\circ} \mathrm{E}$., about 180 miles from Karachi in the Arabian Sea. The Times correspondent at Delhi suggests it may have been near the double ridge which encloses an 8,000-ft. deep gully on the bed of the Arabian Sea. The ridge was first plotted by the John Murray Expedition of $+1933-34$ and is probably a continuation of the Kirthars Range between Sind and Baluchistan. Mr. E. W. Pollard, in the Isle of Wight, recorded the earthquake at 22h. $06 \mathrm{~m} .24 \mathrm{~s}$. G.M.T.

At Karachi the shock was accompanied by rumbling but no damage has been reported except for a few broken windows. The earthquake was felt throughout the Las Bela State of Baluchistan, and at Banjiguar in Baluchistan. A tremendous sea wave, presumably caused by the earthquake, occurred about the same time at several places on the coast. In the Bombay suburbs of Juhu and Versova boats were smashed at their moorings and some people standing on the shore were carried out to sea. The bodies of three women were recovered. It is reported in The Times that the bodies of seven of the nine persons caught by the wave at Mahalaxmi, opposite Bombay's racecourse, have been recovered. Most of the victims appear to have been caught on the causeway connecting an ancient Muslim mosque, which is built on a rocky outcrop, with the mainland. This causeway is usually under water at high tide. The wave was most severe on the coast of Makran, north-west of Karachi. At Pasni a number of people are reported to have been washed away and the post and telegraph office together with other buildings damaged. The Government of India has voted one lakh of rupees for the relief of victims. The damage and loss of life, though great, is thought at the moment to have been estimated too high, and official figures are awaited. The officer in command of the Royal Indian Navy warship Hindustan, the first relief ship to reach the coastal area in question, has signalled news of two new islands in the Arabian Sea about 180 miles west of Karachi. They are stated to have appeared after the recent earthquake and 
to be three miles apart. One has an area of about one square mile and the other one and a half square miles.

In the past, a great earthquake occurred in the State of Cutch on June 16, 1819. This earthquake caused damage over a vast area and extensive changes in level in the crust of the earth. In Bhuj nearly 7,000 houses were overthrown and 1,140 bodies taken from the ruins. Half the town of Anjar was also destroyed with large loss of life. More recently, earthquakes have also occurred in Baluchistan in 1919 and 1931 (Nature, April 27, 1935, p. 661). It appears fortunate that the recent earthquake occurred beneath the sea some miles from land, as otherwise, with a shock so tremendous, without doubt there would have been enormous damage to property and loss of life.

\section{A Biological Council}

MANY biologists have felt for some time past that the activities of the specialized societies to which they belong remain largely unknown to other biologists who happen to belong to different societies or associations, although often the activities of these other societies are of direct interest to them. The officers of various biological societies have frequently felt the need for more information about the arrangements made by their fellows so as to avoid unnecessary clashes of dates of meetings or duplication of discussions on subjects that might advantageously form the basis of a joint meeting. In an endeavour to provide some common meeting ground for the representatives of the various biological societies, the Committee of the Biochemical Society in the autumn of 1944 called an informal meeting of representatives of a few societies which it was thought might be interested in the proposal. In all, three meetings, attended by representatives of fourteen biological societies, were held afterwards in the rooms of the Royal Society.

It was finally decided that a Biological Council should be formed consisting of the representatives of the various societies which were sympathetic to the scheme. The first meeting of this Council, at which Sir Henry Dale took the chair, was held recently in the Linnean Society's rooms. Dr. W. P. K. Findlay, of the Forest Products Laboratory, Princes Risborough, Dr. W. T. J. Morgan, of the Lister Institute of Preventive Medicine, London, and Prof. J. Z. Young, University College, London, were elected secretaries. While the immediate objects of the Council will probably be limited to such matters as the dates and subjects of the general meetings of societies, it is envisaged that the scope of the Council's work may enlarge and that many editorial and other problems relating to the societies' publications may fruitfully be discussed in common.

\section{Plant Pathology in Palestine}

ON the occasion of his seventieth birthday in November 1944, Prof. Chaim Weizmann was presented with a volume of researches by members of the Division of Plant Pathology of the Agricultural Research Station, Rehovoth, Palestine. This volume, describing researches carried out under war conditions, testifies to the zeal and energy of the phytopathological staff of the Station. The subjects dealt with cover a wide range, and include diseases of lettuce, beans, cucumbers, tomato, potatoes, citrus, cereals, clover, apple and pear scab, and fungicides. All the papers have since appeared in the Palestine
Journal of Botany, but the collection brought together is a worthy tribute to a great leader. The remarkable progress in agriculture effected by the Jews in Palestine has no doubt been greatly fostered by the help and assistance afforded by the work of the Agricultural Research Station at Rehovoth. Of the many interesting items mention, may be made of four only : a rare parasite of potatoes is constituted by powdery mildew, due to an unidentified species of Oidium, which first became epidemic in 1941, and again in 1942 and 1943 ; the occurrence of the apple and pear scab in all parts of Palestine but on local varieties only, as the European varieties are some weeks later in growth and regularly escape infection; the novel and ingenious suggestion of using the overhead system of irrigation, now largely in vogue in Palestine, for the application of fungicides; and the occurrence of Ustilago nigra on barley, the first record of this species of smut outside North America, and of immediate practical importance as this pathogen is susceptible to seed disinfectants.

\section{British Radio Industry}

The fundamental scientific principles of radiolocation and the startling results obtained from its application during the War have now become common knowledge. While the conception of this important new weapon is a tribute to British scientific research, and its success in practice demonstrates the ability of the Fighting Services to utilize a highly technical development, there is a necessary intermediate factor, which must not be forgotten, in the form of the design and production facilities available during the time of the country's direst need. The Radio Industry Council has dealt with this last aspect of the subject in a booklet recently issued under the title "The British Radio Industry in War and Peace" (Radio Industry Council, 59 Russell Square, London, W.C.1). The object of this small publication is to tell the world what British men of seience, engineers and workpeople have accomplished in the past five years in the application of the whole field of radio technique to war-time requirements, and the manner in which the experience gained during this terrific effort will be applied to the post-war development of broadcasting and television receiver production.

The British radio industry, which in 1935 produced nearly two million broadcasting receivers for ordinary listeners, was the main source of supply of the technical personnel required by the Services during the War to instal, operate and maintain radiolocation and communication equipment. In spite of this loss of some of its most valuable workers, the radio industry was called upon to supply, at high pressure, tremendous quantities of equipment and components of all types. A typical and impressive example of the scale of the radio equipment required is given by the fact that in any one of our thousand bomber raids many thousands of valves, cathode ray tubes and other electronic devices were in the air with those machines; while at the same time there were further very substantial quantities of all kinds of co-operating equipment in use on the ground. The Radio Industry Council has developed largely from the industry's war-time growth, and it is actively engaged in co-ordinating and furthering the interests of the whole radio manufacturing industry through the four independently constituted associations which deal respectively with the manufacture of valves, components, complete equipments and with general radio communications and electronic engineering. 